\title{
Evaluation of Induced Molting Methods on the Livability and Reproductive System Regression of Japanese Quails (Coturnix japonica)
}

\begin{abstract}
Author(s)
Teixeira RSC ${ }^{1}$

Cardoso $\mathrm{WM}^{2}$

Nogueira $\mathrm{GC}^{3}$

Câmara $\mathrm{SR}^{1}$

Romao $\mathrm{JM}^{3}$

Siqueira $A A^{3}$

Sampaio $\mathrm{FAC}^{3}$

Moraes TGV ${ }^{3}$

Campello $\mathrm{CC}^{4}$

Buxade $\mathrm{CC}^{5}$

1 Mestrando do Programa de Pós-Graduação em Ciências Veterinária, UECE. Fortaleza.

2 Estudante de Graduação da Faculdade de Veterinária,UECE. Fortaleza.

3 Professor do Programa de Pós-Graduação em Ciências Veterinária, UECE. Fortaleza.

4 Professor Adjunto da Faculdade de Veterinária / Laboratório de Histologia, UECE. Fortaleza.

5 Professor Titular da Escuela Técnica Superior de Ingenieros Agrónomos, Universidad Politécnica de Madrid

Laboratório de Estudos Ornitológicos da Faculdade de Veterinária da Universidade Estadual do Ceará
\end{abstract}

\section{Mail Address}

William Maciel Cardoso

Av. Rogaciano Leite, 200. Apto 1303. BI. Tulipe Bairro Salinas

60.810-000. Fortaleza, Ce, Brasil

Telefone: 8532411307 ou

31019848 ou 99894742

E-mail: william.maciel@uol.com.br regis_siqueira_teixeira@yahoo.com.br

\section{Keywords}

Forced molting, ovary, oviduct, quail, zinc oxide.

\section{— Acknowledgements}

The authors are very grateful to the support provided by CAPES, which was essential for carrying out this experiment.

Arrived: October / 2006

Approved: June / 2007

\section{ABSTRACT}

This study aimed at evaluating the alternative method of zinc oxide and fasting to induce molt in Japanese quails. A total number of 190 48-week-old quails was used. They were at end of laying cycle, and presented low egg production. Quails molted by zinc oxide (Z) were fed a diet containing 25,000 ppm of zinc oxide, and received water ad libitum. Quails treated by fasting $(F)$ received no feed and a day of water restriction. The treatment period was determined by the experimental level of body weight loss (BWL). Birds were submitted to different levels of BWL in order to analyze reproductive system regression (ovary + oviduct), and livability. The following groups were established according to their BWL: Control (untreated quails); $F_{25}$ (25\% BWL by $F$ ); $F_{35}(35 \%$ BWL by F); $Z_{25}$ (25\% BWL by Z), and $Z_{35}$ (35\% BWL by Z). $Z_{25}, Z_{35}$, and $F_{35}$ presented no significant differences in reproductive system w eights after molting; however, their weights were lower than $F_{25} . Z_{25}, Z_{35}$, and $F_{35}$ presented the following livability: $97.5,72.5$, and $90 \%$. Japanese quails treated by the alternative method of zinc oxide, presenting body weight loss of $25 \%$, showed low mortality rate, and adequate regression of the reproductive organs.

\section{INTRODUCTION}

Japanese quails (Coturnix japonica) derive from China and Japan, and they are the most important species in the worldwide quail production (Tobón et al., 2002), having an excellent egg production performance.

During the last few years, many researches were carried out on poultry management, nutrition, and health, promoting considerable advances in poultry production. However, little is known on quail management (Souza et al., 2004). Techniques designed for chickens are usually adapted to quail production. Induced molt is an example of a widely used tool in layer management programs (Berry \& Brake, 1985, Hussein et al., 1988; Breeding et al., 1992; Tilbrook et al., 1992; Hussein, 1996; Berry, 2003); however, due to lack of research involving quails, there are no results that prove the efficacy of this technique in quail production. Induced molting is used in the poultry industry to increase the reproductive lifespan of layers leading to new laying cycles (Laurentiz et al., 2005). As the layers get older, their egg production and egg external quality decrease (Keshavarz, 1994; Hurwitz et. al.; 1998). Forced molting can restore their reproductive system capacity, and promote a new laying cycle (Colvara et al., 2002).

Body weight loss, feather replacement, and cessation of egg production are parameters used to determine the efficacy of molting. Albuquerque et al. (1999) observed that hens submitted to the most severe feather replacement presented higher post-molting production. As to body weight loss (BWL), research studies point out that BWL levels 
Teixeira RSC, Cardoso WM, Nogueira GC, Câmara SR, Romao JM, Siqueira AA, Sampaio FAC, Moraes TGV, Campello CC, Buxade CC

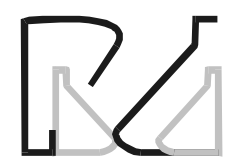

Evaluation of Induced M olting Methods on the Livability and Reproductive System Regression of Japanese Quails (Coturnix japonica) between 25 and 30\% promote better post-molting production in a second laying cycle (Baker et al. 1983; Hussein, 1996). However, according to Brake and Thaxton (1979), post-molting productive improvement is related to the regression and to the regeneration of the reproductive system cells. M ehner (1969), quoted by Giampauli et al. (2005), showed that a decrease in reproductive system activity causes regeneration of the glands of the uterine mucosa. Therefore, post-molting results are associated with organ regression levels obtained during the molting process (Ruszler, 1998). Also, the reduction in the ovary weight depends on the duration of fasting or BWL level (Berry, 2003).

Among several molting methods, fasting and zinc oxide are highlighted. Fasting is commonly used in hens (Ruzler, 1998) due to its low cost and simple use (Hussein, 1996). Due to animal stress, the inclusion of relatively high zinc concentrations in feeds has been extensively studied as a possible alternative to feed deprivation (Berry \& Brake 1985; McCormick \& Cunningham 1987). For a long time, zinc oxide efficiency was supposed to be promoted by its anorexic effect (McCormick \& Cunningham 1987). However, zinc oxide also showed to be more efficient for egg laying cessation and post-molting production as compared to feed deprivation methods (Berry, 1984).

The objective of this study was to determine which induced molting method causes better reproductive system regression and livability of Japanese quails (Coturnix japonica) treated with the alternative method of zinc oxide or fasting.

\section{MATERIAL AND METHODS}

The study started on M arch, 2006. It was performed at the Ornithological Studies Lab of the Veterinary School of the State University of Ceará, Brazil. A total number of 190 quails was used. Quails were 48 weeks old at the end of the laying cycle, and presented low egg production. Birds were individually weighed, identified, and housed in experimental cages with five birds per cage at a density of $106 \mathrm{birds} / \mathrm{m}^{2}$. Birds were supplied with 17 hours/day of light during the experiment.

Two methods of induce molting were applied: Zinc Oxide M ethod (Z) or Fasting (F). Quails were submitted to different levels of body weight loss in both treatments (BWL): $0 \%, 25 \%$, or $35 \%$. Birds in group $Z$ were supplied with water ad libitum and layer feed containing 25,000 ppm of zinc oxide. Birds in group $F$ were submitted to a day of water restriction and feed deprivation until the end of treatment. Treatment duration was relative to the achievement of desired BWL by the birds $(0 \%, 25 \%$ or $35 \%)$, and varied from 3 days up to 5 days in both treatments.

\section{Experimental groups}

The analysis of reproductive organs regression was performed with 30 birds. These were divided into the following groups: Control (untreated quails, $n=6$ ); $F_{25}$ Group ( $25 \%$ of BWL by $F, n=6$ ); $F_{35}$ Group ( $35 \%$ of BWL by $F, n=6) ; Z$ Group ( $25 \%$ of BW L by $Z, n=6$ ) and $Z_{35}$ Group ( $35 \%$ of BWL by $\left.Z, n=6\right)$. Quails were euthanized, and had their reproductive organs collected. Ovary weight $(\mathrm{g})$, oviduct weight $(\mathrm{g})$, reproductive system weight $(\mathrm{g})$, oviduct length $(\mathrm{cm})$, and percentage of reproductive organs weight relative to body weight $(\mathrm{g})$ were evaluated. All data of molted quails were compared to control group. After organ collection, the ovary and the oviduct were separately weighed, using an analytical scale, and oviduct length was measured.

Mortality was analyzed for each treatment in order to determine the effect of induced-molting method on livability. A total number of 160 quails was divided into the same categories as before $\left(\mathrm{F}_{35}, \mathrm{Z}_{25}, \mathrm{Z}_{35}\right.$, and Control), except for $\mathrm{F}_{25}$, each comprising 40 birds.

\section{Statistical Analysis}

Data were initially submitted to the KolmogorovSmirnov and Shapiro-Wilk tests to confirm normality distribution, and to the Bartlett test to verify variance homogeneity among the treatments. When statistical demands for analysis of variance were complied, this analysis was carried out using GLM procedures of SAS software (1999). Test for comparison of means were selected according to the criteria established by Sampaio (2002): variables with a coefficient of variation (CV) of up to $15 \%$ had their means compared by the Student-New man-Keuls (SNK) test, whereas those with CV higher than 15\% had their means compared by the test of Duncan (comparisons involving more than four treatments) and by Student's ttest(comparison involving up to four treatments). When essential statistical demands to perform the Analysis of Variance were not met, Kruskal-Wallis nonparametrical test was used. Means were considered significantly different when $p<0.05$, and the results were expressed as mean \pm standard deviation.

\section{RESULTS AND DISCUSSION}

Table 1 shows the regression of oviduct length, 
ovary w eight, oviduct weight, and reproductive system weight at different levels of body weight loss.

According to oviduct length regression results, we verified that all groups achieved significant reductions as compared to the control group, except for $\mathrm{F}_{25}$. Quails treated with zinc oxide and those submitted to fasting with $35 \%$ BWL presented no significant regression differences, independent of body weight loss. As to ovary weight, all induced-molting groups presented significantly low er results than control group. How ever, birds belonging to groups $Z_{25}, Z_{35}$ and $F_{35}$ achieved regressions of $0.47 \mathrm{~g}, 0.46 \mathrm{~g}$ e $0.47 \mathrm{~g}$ in body weight, with percentages of $92.153 \%, 92.337 \%$ e $92.137 \%$, respectively, but these were not statistically different. These results are consistent with those of Berry \& Brake (1985), who used the fasting method with BWL of 30 to $34 \%$, during 16 days in commercial layers, and observed ovary weight regression of $91.18 \%$. Quails in group $F_{25}$ showed $81.479 \%$ of ovary weight reduction. Souza et al. (2006), studying fasting to induce molting in commercial layers, obtained a $78.36 \%$ regression, and considered it to be insufficient. Groups $Z_{25}, Z_{35}$, and $F_{35}$ presented oviduct weight values of $1.87 \mathrm{~g}, 1.76 \mathrm{~g}$, and $1.79 \mathrm{~g}$, respectively, after forced molting. These groups showed the highest regressions, and were not significantly different among each other. Except for the quails submitted to the 25\% BWL fasting, all results are consistent with El-Deek \& Al-Harthi (2004), who, studying induced molting in hens, observed no difference in ovary weight, oviduct weight and length of hens fed 20,000 ppm zinc oxide in the feed, submitted to feed restriction, or submitted to fasting. Araújo et al. (2006), analyzing the ovary and the oviduct on different days post-molting, concluded that reproductive system biometrics was not different in layers submitted to fasting or to the method of 20,000 ppm zinc oxide dietary inclusion. Quails molting by fasting at $25 \%$ BWL did not present satisfactory reduction of oviduct length, ovary weight, oviduct weight, and reproductive system weight parameters. This may be explained by the insufficient time for the regression of the reproductive system. Brake (1993) found that uterine lipids of commercial layers initiate their mobilization process only after the ninth day of treatment or when the bird reaches $25 \%$ body w eight loss. Berry (2003) observed that, using the fasting method, commercial layers with $25 \%$ BWL were able to achieve complete ovary regression. Our experiment showed that this finding is valid only for zinc oxidetreated birds. Fasting method was not able to achieve full regression of the reproductive organs of quails.

Table 2 shows reproductive organ weights relative to body weight obtained by different Body Weight Loss levels. It can be seen that the lowest reproductive system weights were obtained by the $Z_{25} ; Z_{35}$ e $F_{35}$ groups, with respective results of $2.34 \mathrm{~g}, 2.22 \mathrm{~g}$, and $2.59 \mathrm{~g}$, but with no significant difference. Birds from group $F_{25}$ presented higher reproductive system weights ( $p<0.05)$ as compared to the other inducedmolting groups, with $52.528 \%$ reduction of its initial weight. Garcia et al. (2001), using a three-day fasting, obtained $25.64 \%$ BWL with $31.67 \%$ reduction in reproductive system weight. Lavor (2004) submitted Japanese quails with different body weights to a fourday feeding with 20,000 ppm zinc oxide feed, and found reproductive system reductions varying from $53.66 \%$

\begin{tabular}{|c|c|c|c|c|c|c|}
\hline \multirow[t]{2}{*}{ Treatment } & \multicolumn{2}{|c|}{ Oviduct length } & \multicolumn{2}{|c|}{ Ovary weight } & \multicolumn{2}{|c|}{ Oviduct weight } \\
\hline & $(\mathrm{cm})$ & Regression(\%) & (g) & Regression(\%) & (g) & Regression(\%) \\
\hline Control & $27,27 \pm 3,00^{a}$ & 0 & $5,62 \pm 0,96{ }^{a}$ & 0 & $7,06 \pm 1,25^{a}$ & 0 \\
\hline$Z_{5}$ & $17,80 \pm 3,23^{c}$ & 34,73 & $0,47 \pm 0,14 c$ & 92,15 & $1,87 \pm 0,64^{c}$ & 73,53 \\
\hline $\mathrm{F}_{25}$ & $25,20 \pm 4,83^{a b}$ & 7,58 & $1,11 \pm 0,60^{b}$ & 81,48 & $3,51 \pm 1,25^{b}$ & 50,31 \\
\hline$Z_{35}^{25}$ & $19,00 \pm 3,42^{c}$ & 30,33 & $0,46 \pm 0,06 c$ & 92,34 & $1,76 \pm 0,33^{c}$ & 75,00 \\
\hline$F_{35}^{33}$ & $22,08 \pm 2,99 b c$ & 19,01 & $0,47 \pm 0,08 c$ & 92,14 & $1,79 \pm 1,07^{c}$ & 74,69 \\
\hline
\end{tabular}

Different letters in the same column indicate significant difference $(p<0.05)$.

\begin{tabular}{|c|c|c|c|c|}
\hline Treatment & $\begin{array}{l}\text { Initial Body } \\
\text { weight (g) }\end{array}$ & $\begin{array}{l}\text { Reproductive tract } \\
\text { weight (g) }\end{array}$ & $\begin{array}{l}\text { (\%) Reproductive tract } \\
\text { based on body weigh }\end{array}$ & $\begin{array}{l}\text { (\%) Reproductive } \\
\text { tract regression }\end{array}$ \\
\hline Control & 150,17 & $12,68 \pm 1,24$ & $8,44 \pm 0,62$ & - \\
\hline$Z_{25}$ & 153,17 & $2,34 \pm 0,71^{c}$ & $2,04 \pm 0,54^{c}$ & 71,84 \\
\hline$F_{25}^{25}$ & 155,17 & $4,61 \pm 1,75^{b}$ & $4,01 \pm 1,44^{b}$ & 52,53 \\
\hline$Z_{35}^{25}$ & 142,83 & $2,22 \pm 0,36^{c}$ & $2,38 \pm 0,47^{c}$ & 75,88 \\
\hline $\mathrm{F}_{35}^{35}$ & 137,50 & $2,59 \pm 0,85^{c}$ & $2,51 \pm 1,21^{c}$ & 70,30 \\
\hline
\end{tabular}

Different letters in the same column indicate significant difference $(p<0.05)$. 
Teixeira RSC, Cardoso WM, Nogueira GC, Câmara SR, Romao JM, Siqueira AA, Sampaio FAC, Moraes TGV, Campello CC, Buxade CC

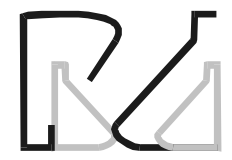

Evaluation of Induced Molting Methods on the Livability and Reproductive System Regression of Japanese Quails (Coturnix japonica) to $66.2 \%$. The other treatments achieved reproductive system regression over $70.302 \%$.

Table 3 shows egg production during treatment up to the post-molting production.

All quails submitted to molting showed a cessation in egg production. Quails of groups $Z_{25}$ and $Z_{35}$ presented total cessation of egg production only on the fourth day of treatment, while birds of the $F_{35}$ group stopped laying on the third day of molting. The new productive cycle (egg production higher than $5 \%$ ) was observed on the tenth day of post-molting treatment in all groups. Biggs et al. (2004) used induced molting in layer hens through fasting, and six days were needed for egg production to cease. Bar et al. (2003), studying several molting programs, found that $25,000 \mathrm{ppm}$ zinc oxide feed caused a faster egg laying cessation. The faster cessation of quail egg production as compared to commercial layers is probably explained by the quail's fast metabolism, which was verified by Blem (1978). Our study showed that quails submitted to fasting methods completely stopped laying one day earlier than birds treated with zinc oxide.

Figure 1 shows quail livability from the beginning of induced molting until beginning of productive period. In the Control, $Z_{25}$ and $F_{35}$ groups, there were no significant differences in livability during the analyzed period, with respective values of $100 \%, 97.5 \%$, and $90 \%$ of live birds, which means $0 \%, 2.5 \%$, and $10 \%$ mortality. In the $Z_{35}$ group, induced molting resulted in significant differences in livability $(p<0.05)$ as compared to the other groups, with a percentage of $72.5 \%$. Zamprônio et al. (1996), using the fasting method in quails, obtained $23.24 \%$ and $25.44 \%$ mortality on the third and sixth molting day, respectively. Garcia et al. (2001) observed mortality rates of $2.04 \%$ and $4.60 \%$ on the second and third day of molting also using the same technique in quails. Silva et al. (2003), utilizing virginiamycin in layer feeds before fasting, found a 1\% mortality rate. According to Buxadé (2000), mortality occurring during induced molting in commercial layers varies from 1 to $1.5 \%$, which means that the result that was most consistent with this study was that of group $Z_{25}$. The other groups presented higher mortality rates.

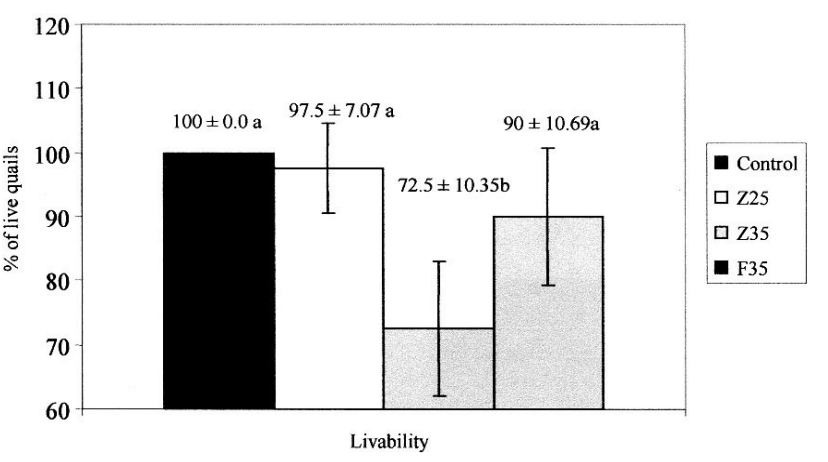

Figure 1 - Livability of quails submitted to different Body Weight Loss levels during induced molting

\section{CONCLUSION}

Japanese quails submitted to $25 \%$ body w eight loss through the alternative method of zinc oxide presented satisfactory regression of the reproductive organs, as well as a low mortality.

\section{REFERENCES}

Albuquerque R, Mendonca Jr. CX, Ghion E. Effect of different methods of forced molt on performance of laying hens. Brazilian Journal of Veterinary Research and Animal Science 1999; 36(3). Disponível em: <http://www.scielo.br/>. Acesso em: 24 out. 2006.

Araújo CSS, Baraldi-Artoni SM , Junqueira OM , Laurentiz AC, Gomes GA. Avaliação macroscópica do oviduto em poedeiras comerciais submetidas a diferentes métodos de muda forçada. In: Conferência APINCO de Ciência e Tecnologia Avícolas; 2006; Santos, BR. Campinas: FACTA; 2006.

Baker M, Braker J, McDaniel GR. The relationship between body weight loss during an induced molt and postmolt egg production, egg weight, and shell quality in caged layers. Poultry Science 1983; 62(3):409-413.

Bar A, Razaphkovsky D, Shinder D, Vax E. Alternative procedures for molt induction: pratical aspects. Poultry Science 2003; 82(4):843550.

Berry WD. A physiological comparison of methods for induced molting in the laying hen [M.Sc. Thesis]. Raleight (NC) : North Carolina State University; 1984.

Berry WD, Brake J. Comparison of parameters associated with molt

\begin{tabular}{|c|c|c|c|c|c|c|c|c|c|c|c|}
\hline \multirow{2}{*}{ Method } & \multicolumn{11}{|c|}{ Days since beginning of treatment } \\
\hline & *Production & 1 & 2 & 3 & 4 & 5 & 6 & 7 & 8 & 9 & 10 \\
\hline Control & 62,5 & 57,5 & 62,5 & 50 & 55 & 50 & 52,5 & 50 & 57,5 & 62,5 & 60 \\
\hline$Z_{25}$ & 60 & 57,5 & 2,5 & 2,5 & 0 & 0 & 0 & 0 & 0 & 0 & 5,26 \\
\hline$Z_{35}^{23}$ & 60 & 57,5 & 2,5 & 2,56 & 0 & 0 & 0 & 0 & 2,94 & 0 & 10,34 \\
\hline$F_{35}^{35}$ & 62,5 & 60 & 5,40 & 0 & 0 & 0 & 0 & 0 & 0 & 3,03 & 8,33 \\
\hline
\end{tabular}

* Egg production before forced molting treatments. 
induced by fasting, zinc and low dietary sodium in caged layers. Poultry Science 1985; 64(11):2027-36.

Berry WD. The physiology of induced molting. Poultry Science 2003; 82(6):971-980.

Biggs PE, Persia M E, Koelkebeck KW, Parsons CM . Further Evaluation of Nonfeed Removal M ethods for M olting Programs. Poultry Science 2004; 83:745-52.

Blem CR. The energetics of young Japanese Quail, Coturnix coturnix japonica. Comparative Biochemistry and Physiology 1978; 59:21923.

Brake J, Thraxton P. Physiological changes in caged layers during a forced molt. Gross changes in organs. Poultry Science 1979; 58(3): 707-16.

Brake J. Recent advances in induced moulting. Poultry Science 1993; 72(5):929-31.

Breeding SW, Brake J, Garlich JD. Molt induced by dietary zinc in a low-calcium diet. Poultry Science 1992; 71(1):168-180.

Buxadé CC. La gallina ponedora. Sistema de explotación y Técnicas de producción. Castelo: Mundi-Prensa, 2000. p.389.

Colvara IG, Maier JC, Rutz F, Brum PAR, PAN EA. Níveis de energia metabolizável em rações para poedeiras semipesadas durante 0 segundo ciclo de produção no verão. Revista brasileira de Agrociências 2002; 8(1):47-9.

El-Deek AA, Al-Harthi MA. Post M olt Performance Parameters of Broiler Breeder Hens Associated with Molt Induced by Feed Restriction, High Dietary Zinc and Fasting. International Journal of Poultry Science 2004; 3(7):456-462.

Garcia EA, Mendes AA, Pizzolante CC, Veiga N. Alterações M orfólogicas de Codornas Poedeiras Submetidas a Muda Forçada. Revista Brasileira de Ciências Avícolas 2001; 3(3):265-273.

Giampauli J, Pedroso AA, M oraes VM B. Desempenho e qualidade de ovos de poedeiras após a muda forçada suplementadas com probióticos em diferentes fases de criação. Ciência Animal Brasileira 2005; 6(3):179-86.

Hurwitz S, Wax E, Nisenbaum Y, Benmoshe M, Playnik I. The response of laying hens to induced molt as affected by strain and age. Poultry Science 1998; 77(1):22-31.

Hussein AS, Cantor AH, Johnson TH. Use of high levels of dietary aluminium and zinc for inducing pauses in egg production of japanese quail. Poultry Science 1988; 67:157-65.

Hussein AS. Induced moulting procedures in laying fowl. World's Poultry Science Journal 1996; 52(2):175-87.

Keshavarz K. Laying hens respond differently to high dietary levels of phosphorus in monobasic and dibasic phosfate. Poultry Science 1994; 73(5):687-703.
Laurentiz AC, Filardi RS, Rodrigues EA. Total sulfur amino acids levels for semi heavy weight laying hens after forced molt. Ciência Rural 2005; 35(1):164-68.

Lavor CTB. Níveis de regressão de ovário e oviduto devido a perda de peso corpóreo em Codornas japonesas (Coturnix coturnix japonica) submetidas a muda forçada [dissertação]. Fortaleza (CE): Universidade Estadual do Ceará; 2004.

Mccormick CC, Cunningham DL. Performance and physiological profiles of high dietary zinc and fasting as methods of inducing a forced rest: A direct comparison. Poultry Science 1987; 66:10071013.

Tobón FA, Román MO, Molina S, Bothert JP. Determinación del perfil de ácidos grasos de la secreción de la glándula uropigial de la Coturnix coturnix japonica (codorniz doméstica). Revista Colombiana de Ciencias Pecuarias 2002; 15(2):169-179.

Ruszler PL. Health and husbandry consideration of induced molting. Poultry Science 1998; 77(12):1789-93.

Sampaio IBM. Estatística aplicada à experimentação animal. 2.ed. Belo Horizonte: Fundação de Estudo e Pesquisa em Medicina Veterinária e Zootecnia; 2002. 265p.

SAS/STAT (User's Guide). SAS Institute Inc., Cary, N.C.; 1999.

Silva JHV, Jordao Filho J, Silva EL. Effect of bulb garlic (Allium sativum Linn.), probiotic and virginiamycin before, during and after induced forced molt stress in semi-heavily laying hens. Revista Brasileira de Zootecnia 2003; 32(6):1697-1704.

Souza KM R, Carrijo AS, Garcia AM L, Ramos ACP, Ferreira JZ, Suzuki FM. Métodos alternativos de muda forçada em poedeiras comerciais: peso corporal e órgãos reprodutivos. In: Conferência APINCO de Ciência e Tecnologia Avícolas; 2006; Santos, BR. Campinas: FACTA; 2006.

Souza LM G, Murakami AE, Sakamoto MI, Furlan AC, Franco JRG, Bruno LDG. Formas de Processamento da ração para codornas em postura (Coturnix coturnix japonica). In: Anais do 2은 Simpósio Internacional e 1을 Congresso Brasileiro de Coturnicultura; 2004; Lavras, BR. Lavras: UFLA; 2004.

Tilbrook AJ, Johnson RJ, Clarke IJ. Short term reduction in egg production in laying hens treated with an agonist of $\mathrm{GnRH}$. British Poultry Science 1992; 33(3):541-543. 